\title{
Complex relationships
}

OPEN

Josep Dalmau, MD, PhD This issue of Neurology ${ }^{\circledR}$ Neuroimmunology \& Neuroinflammation (N2) contains articles on a variety of interesting topics demonstrating the complexity of the relationships of the immunologic system with diseases beyond autoimmunity such as neurodegenerative disorders. I have highlighted a few of these studies below.

Immunologic profiling is central to the study of autoimmune diseases and the development of personalized medicine. In this issue of N2, several immune profiling studies provide novel observations. Dooley et al. ${ }^{1}$ performed multiplex flow cytometry to identify immunologic signatures in untreated and treated patients with multiple sclerosis (MS). They describe systemic immune differences between untreated patients with MS and healthy controls and found that immunomodulatory treatments (interferon- $\beta$, glatiramer acetate, natalizumab, fingolimod) induced unique alterations in the immune profile of the patients. Of note, there were only 2 significant effects shared across treatments and these were B cell-related changes occurring with interferon- $\beta$ and fingolimod. This appears to support recent evidence of the importance of $\mathrm{B}$ cells in MS pathogenesis and treatment. Additional studies explored cytokine measurements and a comparison of results to those of a cohort of subjects with autoimmune thyroid disease. The findings showed that despite shared genetic risk factors, the immunologic changes in MS and autoimmune thyroid disease were different, suggesting complex gene-immune relationships to be elucidated.

The relationship of the immunologic system with neurodegenerative processes is complex and ranges from protective to pathogenic. In amyotrophic lateral sclerosis (ALS), early protective immune responses are replaced by destructive responses with some immune cells playing both sides of the fence at different times. Murdock et al. ${ }^{2}$ used flow cytometry to profile the leukocyte populations in patients with ALS and correlate the findings with clinical metrics of ALS. They found a significant increase in the percentage of neutrophils and a significant decrease in the percentage of
$\mathrm{CD} 4 \mathrm{~T}$ cells and $\mathrm{CD} 16^{-}$monocytes in patients with ALS compared to controls. To evaluate this relationship further, the authors calculated a neutrophil to $\mathrm{CD}_{16}{ }^{-}$monocyte ratio for each patient and found that it was significantly elevated in patients with ALS and increased as the ALS Functional Rating Scale score decreased, suggesting that this ratio may have utility as a biomarker of ALS. In another ALS-focused study, Lu et al. ${ }^{3}$ examine the relationship between inflammatory markers and neuromuscular markers as well as ALS disease stages over time demonstrating longitudinal changes for some markers that may prove useful for prognosis and evaluation of treatment responses.

Another neurodegenerative disorder in which autoimmune mechanisms have been implicated is Parkinson disease. This is supported by the finding that some patients with Parkinson disease develop antibodies against $\alpha$-synuclein. Having previously demonstrated that antibodies to Epstein-Barr virus (EBV) latent membrane protein 1 (LMP1) crossreacted with $\alpha$-synuclein, in this issue of N2, Woulfe et al. ${ }^{4}$ determined the target $\alpha$-synuclein epitope using a commercial LMP1 antibody and then studied several human cohorts with EBV antibodies (none with Parkinson disease) for the presence of crossreactivity with the $\alpha$-synuclein epitope. They demonstrate that a majority of patients with EBV infection develop these antibodies and speculate that molecular mimicry induced by EBV LMP1 may underlie the development of the $\alpha$-synuclein autoantibodies in patients with Parkinson disease. These results provide the basis for conducting epidemiologic studies of EBV infection and risk of Parkinson disease as well as prospective studies of the presence of these crossreactive antibodies in patients with Parkinson disease.

The topic of molecular mimicry is also addressed in the study by Rühl et al. ${ }^{5}$ that provides insight into mimicry involving $\mathrm{CD} 8^{+} \mathrm{T}$ cells in MS. The authors studied a human leukocyte antigen (HLA)-A3restricted human myelin-reactive $\mathrm{CD} 8^{+} \mathrm{T}$ cell receptor, called 2D1, that had been isolated from a patient

From ICREA-IDIBAPS, Hospital Clínic, University of Barcelona, Spain; and Department of Neurology, University of Pennsylvania, Philadelphia. Funding information and disclosures are provided at the end of the editorial. Go to Neurology.org/nn for full disclosure forms.

This is an open access article distributed under the terms of the Creative Commons Attribution-NonCommercial-NoDerivatives License 4.0 (CC BY-NC-ND), which permits downloading and sharing the work provided it is properly cited. The work cannot be changed in any way or used commercially. 
with MS. Using a novel antigen-search technology developed by their group, the authors identified and validated a cross-reactive peptide that was recognized by this clone in the context of HLA-A2. The authors cautiously note that demonstration of mimicry between 2 different HLA class I molecules that present different peptides does not prove clinical relevance. However, this study demonstrates the utility of this method that can be applied to identify candidate antigens of $\mathrm{CD}^{+} \mathrm{T}$ cells from MS lesions.

The diagnostic uncertainty that results from the inability to demonstrate an infectious organism in a patient with an inflammatory CNS disorder can lead to suboptimal treatment. In a pilot study, Salzberg et al. ${ }^{6}$ performed next-generation sequencing of the microbiome in brain or spinal cord biopsies from 10 patients with suspected infections in whom conventional studies were negative or inconclusive. Analyses of the sequencing results identified infectious agents in 3 patients with the pathogen confirmed by other methodologies and in 5 cases clarified the noninfectious nature of the inflammatory process. This is an important study demonstrating the direct clinical utility of next-generation sequencing. More details about the study can be found in the accompanying editorial by Drs. Berger and Wilson.?

In addition to these articles, this issue of N2 contains a consensus paper by Benjamin et al. ${ }^{8}$ aimed at defining and classifying the etiology of arterial ischemic stroke in patients with HIV for which many etiologies are likely inflammatory; a case report by Ikumi et al. ${ }^{9}$ of a patient with MS treated with fingolimod who developed HSV2-related hemophagocytic lymphohistiocytosis; and 2 patients reported by Lioger et al. ${ }^{10}$ who experienced successful treatment with rituximab of cerebral cryoglobulinemic vasculitis associated with Sjögren syndrome.

I hope you will find these and the other articles in this issue of N2 to be of interest and I welcome your comments.

\section{STUDY FUNDING}

No targeted funding.

\section{DISCLOSURE}

J. Dalmau is the editor of Neurology: Neuroimmunology \& Neuroinflammation, is on the editorial board for Neurology UpToDate; holds patents for and receives royalties from $\mathrm{Ma} 2$ autoantibody test, NMDA receptor autoantibody test, $\mathrm{GABA}_{\mathrm{B}}$ receptor autoantibody test, $\mathrm{GABA}_{\mathrm{A}}$ receptor autoantibody test, DPPX autoantibody test, and IgLON5 autoantibody test; and receives research support from EUROIMMUN, NIH, Fundació CELLEX, Instituto Carlos III (CIBERER, and Fondo de Investigaciones Sanitarias). Go to Neurology.org/nn for full disclosure forms.

\section{REFERENCES}

1. Dooley J, Pauwels I, Franckaert D, et al. Immunologic profiles of multiple sclerosis treatments reveal shared early B cell alterations. Neurol Neuroimmunol Neuroinflamm 2016;3:e240. doi: 10.1212/NXI.0000000000000240.

2. Murdock BJ, Bender DE, Kashlan SR, et al. Increased ratio of circulating neutrophils to monocytes in amyotrophic lateral sclerosis. Neurol Neuroimmunol Neuroinflamm 2016;3:e242. doi: 10.1212/NXI.0000000000000242.

3. Lu CH, Allen K, Oei F, et al. Systemic inflammatory response and neuromuscular involvement in amyotrophic lateral sclerosis. Neurol Neuroimmunol Neuroinflamm 2016;3:e244. doi: 10.1212/NXI.0000000000000244.

4. Woulfe J, Gray MT, Ganesh MS, Middeldorp JM. Human serum antibodies against EBV latent membrane protein 1 cross-react with alpha-synuclein. Neurol Neuroimmunol Neuroinflamm 2016;3:e239. doi: 10.1212/NXI. 0000000000000239 .

5. Rühl G, Niedl AG, Patronov A, et al. Multiple sclerosis: molecular mimicry of an antimyelin HLA class I restricted T-cell receptor. Neurol Neuroimmunol Neuroinflamm 2016;3:e241. doi: 10.1212/NXI.0000000000000241.

6. Salzberg SL, Breitwieser FP, Kumar A, et al. Next-generation sequencing in neuropathologic diagnosis of infections of the nervous system. Neurol Neuroimmunol Neuroinflamm 2016;3:e251. doi: 10.1212/NXI.0000000000000251.

7. Berger JR, Wilson MR. Next generation sequencing of tissue: a logical extension. Neurol Neuroimmunol Neuroinflamm 2016;3:e261. doi: 10.1212/NXI.0000000000000261.

8. Benjamin LA, Bryer A, Lucas S, et al. Arterial ischemic stroke in HIV: defining and classifying etiology for research studies. Neurol Neuroimmunol Neuroinflamm 2016;3:e254. doi: 10.1212/NXI.0000000000000254.

9. Ikumi K, Ando T, Katano H, et al. HSV-2-related hemophagocytic lymphohistiocytosis in a fingolimod-treated patient with MS. Neurol Neuroimmunol Neuroinflamm 2016;3:e247. doi: 10.1212/NXI.0000000000000247.

10. Lioger B, Ferreira-Maldent N, Cottier JP, Debiais S, Gyan E, Maillot F. Rituximab for Sjögren syndromeassociated type II mixed cryoglobulinemic cerebral vasculitis. Neurol Neuroimmunol Neuroinflamm 2016;3:e253. doi: 10.1212/NXI.0000000000000253. 


\section{Neurology \\ Neuroimmunology \& Neuroinflammation}

Complex relationships

Josep Dalmau

Neurol Neuroimmunol Neuroinflamm 2016;3;

DOI 10.1212/NXI.0000000000000262

This information is current as of August 4, 2016

\section{Updated Information \& Services}

References

Permissions \& Licensing

Reprints including high resolution figures, can be found at:

http://nn.neurology.org/content/3/4/e262.full.html

This article cites 10 articles, 5 of which you can access for free at: http://nn.neurology.org/content/3/4/e262.full.html\#\#ref-list-1

Information about reproducing this article in parts (figures,tables) or in its entirety can be found online at:

http://nn.neurology.org/misc/about.xhtml\#permissions

Information about ordering reprints can be found online: http://nn.neurology.org/misc/addir.xhtml\#reprintsus

Neurol Neuroimmunol Neuroinflamm is an official journal of the American Academy of Neurology.

Published since April 2014, it is an open-access, online-only, continuous publication journal. Copyright $@$ 2016 American Academy of Neurology. All rights reserved. Online ISSN: 2332-7812.

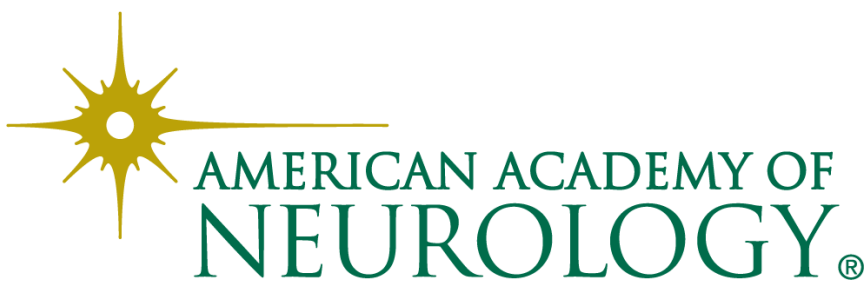

